Our Nature (2012) 10: 167-175

\title{
Taxonomy and Diversity of Genus Pediastrum Meyen (Chlorophyceae, Algae) in East Nepal
}

\author{
S.K. Rai ${ }^{{ }^{*}}$ and P.K. Misra ${ }^{2}$ \\ ${ }^{I}$ Department of Botany, Post Graduate Campus, T.U., Biratnagar, Nepal \\ ${ }^{2}$ Phycology Research Laboratory, Department of Botany, University of Lucknow, India \\ *E-mail: shivarai24244@yahoo.com
}

\begin{abstract}
Pediastrum Meyen is a green algae occurs frequently in lentic environment like pond, puddles, lakes etc. mostly in warm and humid terai region. Twenty taxa of Pediasturm have been reported from Nepal, mostly from central and western part of the country, hitherto. Among them, in the present study, ten taxa of Pediastrum are enumerated also from east Nepal. Taxonomy and diversity of each taxa have been described with photomicrography.
\end{abstract}

Key words: Algae, Chlorophyceae, Pediastrum, Taxonomy, Nepal

\section{Introduction}

Green algae are aquatic plants and act as the pioneer photosynthetic organism or producer in the World of ecosystem. The genus Pediastrum Mayen (Chlorophyceae, Sphaeropleales) is a free floating, coenobial, green algae occurs commonly in natural freshwater lentic environments like ponds, lakes, reservoirs etc. Their occurrence in brackish and salty waters is rare (Parra, 1979). At present, only 24 species of Pediastrum have been described from the World and among them four species $(P$. boryanum, $P$. duplex, $P$. simplex and $P$. tetras) are Worldwide in distribution and occur generally in eutrophic waters (Komárek and Jankovská, 2001). Out of these four, rest other taxa belong to the various different ecological and geographical ranges (Komárek and Jankovská, 2001). Most of the species of Pediastrum are restricted in particular geographical areas or recorded from distant localities (Kowalska and Wolowski, 2010).

The outer layer of cell wall of Pediastrum is composed of sporopollenin combined with silicon oxide which makes them high resistance to decay. Therefore, they remain preserved well in lake sediments as fossil record for palynological studies (Komárek and Jankovská, 2001). Thus, the knowledge of Pediastrum can be useful for the determination of trophocity or salinity of water at present and past (Pasztaleniec and Poniewozik, 2004).

Study on algal flora of Nepal is incomplete and sporadic. The maximum areas of the country still untouched and have to explore extensively. The genus Pediastrum has been little studied in Nepalese water body. Baral (1999) and Prasad (2011) have noted only 11 taxa of Pediastrum from Nepal. At present, including this, the total Pediastrum reported from the country reached to 20 taxa (Tab. 1).

The aim of this study was to determine the flora of Pediastrum with its taxonomy and diversity in Nepal. This study will contribute to the National Algal Database of Nepal. 
Table 1. Total Pediastrum taxa reported from Nepal.

\begin{tabular}{|c|c|c|}
\hline S.N. & Pediastrum taxa & Distribution \\
\hline$\overline{1}$ & $\begin{array}{l}\text { P. angulosum (Ehr.) Menegh. var. rugosum } \\
\text { Racib. }\end{array}$ & $\begin{array}{l}\text { A pond at Pisang, } 3100 \mathrm{~m} \text {, Manang (Hirano, 1955; Hickel, } \\
1973 \text { ) }\end{array}$ \\
\hline 2 & P. biradiatum Meyen & Fish pond at Hetauda, Makawanpur (Sahay et al., 1992) \\
\hline 3 & P. boryanum (Turp.) Menegh. & $\begin{array}{l}\text { A pool above the bridge of Charang, } 770 \mathrm{~m} \text {, Gorkha } \\
\text { (Hirano, 1963) }\end{array}$ \\
\hline 4 & P. boryanum var. longicorne Reinsch & Described in above text. \\
\hline 5 & P. duplex Meyen & Described in above text. \\
\hline 6 & P. duplex var. brachilobum A. Br. & A ditch at Gaindakot, Nawalparasi (Das and Verma, 1996). \\
\hline 7 & P. duplex var. clathratum A. Br. Ex. Lagerh. & $\begin{array}{l}\text { A shallow pool near Phewa lake, } 967 \text { m, Kaski (Hirano, } \\
\text { 1955); Fish pond at Hetauda, Makawanpur (Sahay et al., } \\
\text { 1992); A ditch at Gaindakot, Nawalparasi and Manahari } \\
\text { river at Manhari, Chitwan (Das and Verma, 1996). }\end{array}$ \\
\hline 8 & P. duplex var. gracillium West et G.S. West & Described in above text. \\
\hline 9 & P. duplex var. subgranulatum Racib. & Described in above text. \\
\hline 10 & P. duplex var. reticulatum Lagerh. & $\begin{array}{l}\text { Karra river at Hetauda, Makawanpur (Sahay et al., 1992); } \\
\text { Rapti river and its tributes at Tandi, Chitawan (Das and } \\
\text { Verma, 1996) }\end{array}$ \\
\hline 11 & P. duplex var. rugulosum Racib. & A pond at Pisang, $3100 \mathrm{~m}$, Manang (Hirano, 1955) \\
\hline 12 & P. integrum Näg. f. glabra Racib. & $\begin{array}{l}\text { A pond at Pokhara, } 967 \mathrm{~m} \text {, Kaski and a stream at Tukucha } \\
\text { Moor, } 2600 \mathrm{~m} \text {, Mustang (Hirano, 1955). }\end{array}$ \\
\hline 13 & P. obtusum Lucks & $\begin{array}{l}\text { Bakaya river bank and fish pond at Hetauda, Makawanpur } \\
\text { (Sahay et al., 1992). }\end{array}$ \\
\hline 14 & P. ovatum (Ehr.) A.Br. & Fish pond at Hetauda, Makawanpur (Sahay et al., 1992) \\
\hline 15 & P. simplex Meyen & Described in above text. \\
\hline 16 & $\begin{array}{l}\text { P. simplex var. duodenarium (Bailey) } \\
\text { Rabenh. }\end{array}$ & Described in above text. \\
\hline 17 & P. tetras (Ehr.) Ralfs & Described in above text. \\
\hline 18 & P. tetras var. apiculatum Fritsch & Described in above text. \\
\hline 19 & P. tetras var. excisum (Rabenh.) Hansg. & Described in above text. \\
\hline 20 & P. tetras var. tetraodon Rabenh. & Described in above text. \\
\hline
\end{tabular}

\section{Materials and methods}

Algal samples were collected with the help of plankton-net (mesh size $10 \mu \mathrm{m}$ ) as well as by squeezing the macrophytes from different lotic and lentic habitats of east Nepal (Map 1). The collections were preserved in $4 \%$ formaldehyde solution and then brought to the Algal Research Lab, Department of Botany, P.G. Campus, Biratnagar for further investigation. Temporary glycerin mount slides of each collection were made and studied under light microscope. Microphotographs of each Pediastrum taxa were taken using Nikon E-
400 microscope with H-III photomicrographic attachment. Their taxonomy and identification were confirmed on the basis of Prescott (1951), Tiffany and Britton (1952), Philipose (1967), Wendy (2012) and online available databases viz. WoRMS, ITIS and Algaebase. The taxonomy of the Pediastrum algae were determined by studying their morphological features such as number of cells in the coenobia, outline and shape of the cells, number of lobes/processi, depth of incisions of marginal cells, sculpture of cell wall, dimensions of colony and cells, length of 
lobes/processi etc. Stage and occular micrometers were used for the measurement of algal dimensions. Necessary Cameralucida pictures were also drawn to compare and confirm their morphotaxonomic features.

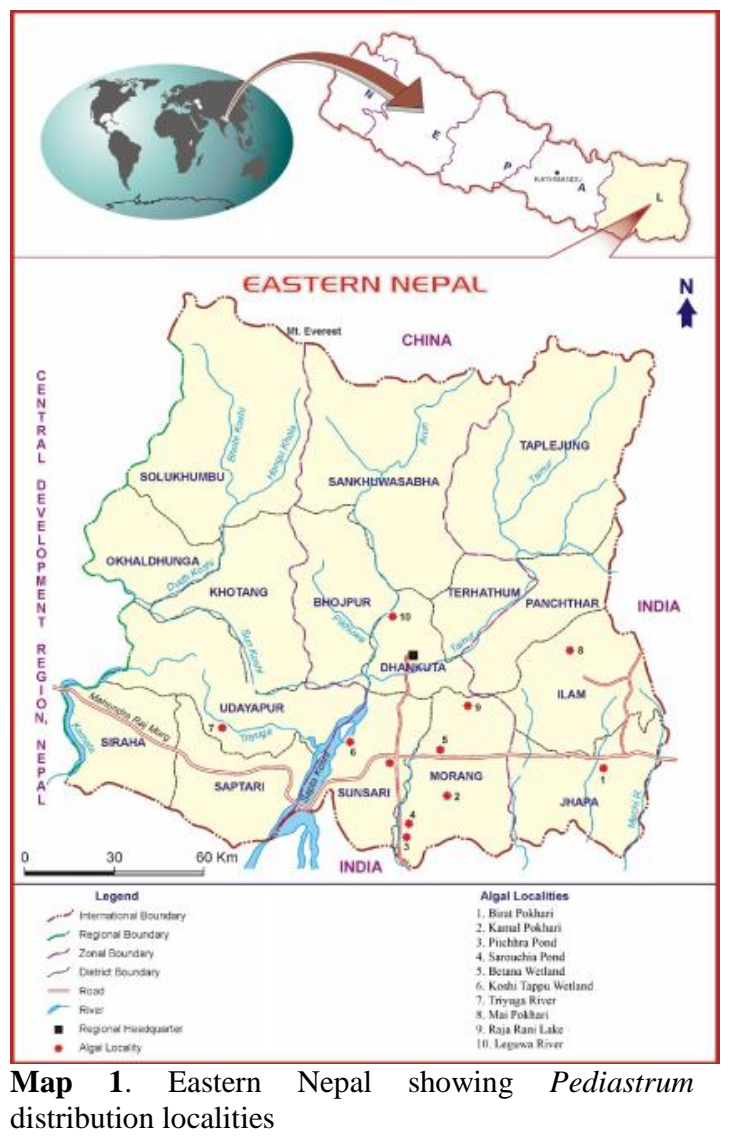

All the samples and slides have been deposited in the algal repository of Department of Botany, P.G. Campus, Biratnagar. Accession numbers of these collections are same as those of the collection numbers. Abbreviations and symbols used in the text are as $\mathrm{CN}=$ Collection number, $\mathrm{DC}=$ Date of collection,
$\mathrm{L}=$ Locality and $\mathrm{D}=$ Distribution in Nepal and Asia.

\section{Results}

Genus: Pediastrum Meyen 1829

A. Systematic position:

Phylum: Chlorophyta

Subphylum: Tetraphytina

Class: Chlorophyceae

Order: Sphaeropleales

Family: Hydrodictyaceae

Genus: Pediastrum Meyen 1829

B. Generic characters: Colonies free floating, disc-shaped to stellate, flat, monostromatic with 4-8-16-32-64 or more polygonal cells, compact or perforate; cells coenocytic, smooth or rough walls, marginal cells with or without process and usually differently shaped than interior cells; chloroplast parietal, disc shaped, in later stages filling entire cell, with 1-4 pyrenoids; reproduction by formation of zoospores, aplanospores, isogametes and zygotes.

C. Key to the species

i. Marginal cells with single projection....... P. simplex

i. Marginal cells with 2 or more projections, or bilobed. ii

ii. Projections simple. ........ iii

ii. Projections emarginated or bidentate.................... tetras

iii. Coenobium perforate ...........P. duplex

iii. Coenobium entire, projections end into linear teeth. P. boryanum

D. Taxonomic description: A total ten Pediastrum taxa reported from east Nepal are described below. 
1.Pediastrum boryanum (Turpin) Meneghini var longicorne Reinsch (Fig. 7)

Prescott, G.W. 1951, P. 222, Pl. 47, Fig. 10; Tiffany, L.H. and M.E. Britton 1952, P. 112, Pl. 30, Figs. 295, 296; Philipose, M.T. 1967, P. 119, Fig. 40b.

Colonies circular to oval, usually $16-32$ celled, up to 256 celled; cells arranged in concentric rings without intercellular space; inner cells polygonal with straight sides, outer face of peripheral cells emarginated and extended into two longer processes ending into swollen stumpy spines; cell wall usually granulated or smooth; cells up to 40 $\mu \mathrm{m}$ in diameter, processes $10-30 \mu \mathrm{m}$ long.

L: Epiphytic on the roots of Eichhornia crassipes (Mart.) Solms at Koshi Tappu wetland, 206 m, Kusaha, Sunsari.

CN : SK 57, DC : 20-06-2011.

D : Nepal - a pool above the bridge of Charang, 770 m, Gorkha (Hirano, 1963); India (Philipose, 1967), Taiwan (Anon., 2012).

\section{Pediastrum duplex Meyen (Figs. 8, 9)} Prescott, G.W. 1951, P. 223, Pl. 48, Fig. 4; Tiffany, L.H. and M.E. Britton 1952, P. 112, Pl. 30, Fig. 300; Philipose, M.T. 1967, P. 121, Fig. 43b.

Colonies usually of $16-32$ celled, sometimes $4,8,64$ or 128 celled with small lens shaped perforations between cells; inner cells quadrate to angular in shape, inner side of marginal cells concave, outer side produced into two short truncate processes; colonies $38-90 \mu \mathrm{m}$ in diameter; marginal cells $13 \mu \mathrm{m}$ long, 9-11.5 $\mu \mathrm{m}$ broad; inner cells $11 \mu \mathrm{m}$ long, 8-9 $\mu \mathrm{m}$ broad.
L : Epiphytic on the roots of Pistia stratiotes L. at Pitchhra pond, $72 \mathrm{~m}$, Biratnagar, Morang.

CN : SK 44, DC : 11-06-2011.

D : Nepal - Rupa, Phewa, Begnas, and Khaste lakes, 900 m, Pokhara, Kaski (Hickel, 1973); Fish pond at Hetauda, Makawanpur (Sahay et al., 1992); Municipal drain near Bus Stand, Narayanghat, Chitwan (Das and Verma, 1996); China (Cao et al., 2005; Hu and Wei, 2006), India (Arulmurugan et al., 2010), Singapore (Phamet al., 2011), Taiwan (Yamamoto and Shiah, 2012).

3. Pediastrum duplex Meyen var. gracillium West et G.S. West [Current accepted name: Lacunastrum gracillium (West et G.S. West) H. McManus] (Fig. 6)

Biswas, K. 1949, P. 67, Pl. 3, Fig. 28; Prescott, G.W. 1951, P. 224, Pl. 48, Fig. 12; Philipose, M.T. 1967, P. 124, Figs. 43 h-i.

Colonies with large intercellular spaces; cells narrow, as broad or narrower than the processes; marginal cells curved outwards and with two long processes with emarginated apex; inner cells also similar to marginal cells but with shorter processes; colonies $50-52 \mu \mathrm{m}$ in diameter; marginal cells $13-16.5 \mu \mathrm{m}$ long, $8-10 \mu \mathrm{m}$ broad; inner cells 12.5-14.5 $\mu \mathrm{m}$ long, 9.5-13.5 $\mu \mathrm{m}$ broad.

$\mathrm{L}$ : Planktonic in the stagnant water at Kamal Pokhari, 73 m, Sukrabare, Kechana, Morang.

CN : SK 79, DC : 05-07-2011.

Distribution: Nepal - Fish pond at Hetauda, Makawanpur (Sahay et al., 1992); Pond 
near Mahendranagar Bazar, Kanchanpur (Chaturvedi and Habib, 1996); China (Hu and Wei, 2006), India (Biswas, 1949), Singapore (Pham et al., 2011), Taiwan (Anon., 2012).

4. Pediastrum duplex var. subgranulatum Raciborski (Fig. 11)

Bruehl, P. and K. Biswas 1926, P. 269, Pl. 6, Figs. 43 a-b; Philipose, M.T. 1967, P. 125, Fig. 43j; Komarek, J. 1983, P. 82, Figs. 7 a-d.

Colonies 16-64 celled; cells and intercellular spaces similar as in P. duplex; cell wall granulate; colonies $108-118 \mu \mathrm{m}$ in diameter; marginal cells $18.5 \mu \mathrm{m}$ long, 18$19 \mu \mathrm{m}$ broad; inner cells $20 \mu \mathrm{m}$ long, $16 \mu \mathrm{m}$ broad.

L : Epiphytic on the roots of Eichhornia crassipes (Mart.) Solms at Birat Pokhari, 135 m, Anarmani, Jhapa.

CN : SK 97, DC : 28-07-2011.

D : Nepal - Phewa lake, 967 m, Pokhara, Kaski (Hickel, 1973); India (Philipose, 1967).

5. Pediastrum simplex Meyen [Current accepted name: Monactinus simplex (Meyen) Corda] (Figs. 5, 12)

Prescott, G.W. 1951, P. 227, Pl. 50, Fig. 2; Tiffany, L.H. and M.E. Britton 1952, P. 110, Pl. 30, Figs. 290-291; Philipose, M.T. 1967, P. 113.

Colonies circular to oval, 5-8-16-32 celled; inner side of marginal cells more or less straight, outer side produced into a gradually tapering process, sides concave; inner cells polygonal; intercellular space usually absent but if present they are small and few in number; cell wall smooth or punctate to granulate; colonies $70-100 \mu \mathrm{m}$ in diameter; cells 19-26 $\mu \mathrm{m}$ long, $8-13 \mu \mathrm{m}$ broad.

$\mathrm{L}$ : Planktonic in the stagnant water at Mai Pokhari, 2150 m, Ilam.

CN : SK 85, DC : 10-07-2011.

D : Nepal - Phewa lake, 967 m, Kaski (Hickel, 1973); Pakistan (Mehwish and Aliya, 2005), China (Cao et al., 2005), India (Philipose, 1967), Singapore (Pham et al., 2011), Taiwan (Anon., 2012).

6. Pediastrum simplex var. duodenarium (J.W. Bailey) Rabenhorst (Current accepted name $P$. simplex Meyen) (Fig. 10)

Prescott, G.W. 1951, P. 227, Pl. 50, Figs. 45; Tiffany, L.H. and M.E. Britton 1952, P. 110, Pl. 30, Fig. 292; Philipose, M.T. 1967, P. 115, Figs. 36 d-h.

Colonies usually 8-16-32 celled; it differs from $P$. simplex having large intercellular spaces; inner side of marginal cells concave, outer side produced a single delicately tapering process; inner cells similar to marginal cells but with shorter processes; cell wall smooth or finely punctate; colonies 63-97 $\mu \mathrm{m}$ in diameter; marginal cells $18-29$ $\mu \mathrm{m}$ long, 9-15 $\mu \mathrm{m}$ broad; inner cells $10-15$ $\mu \mathrm{m}$ long, $9-14 \mu \mathrm{m}$ broad.

L : Epiphytic on the leaf of Blyxa japonica (Miq.) Maxin. Ex Aschers and Gurke at Betana pond, $123 \mathrm{~m}$, Belbari, Morang.

CN : EN 39, DC : 04-06-2011.

D: Nepal - Fish pond, Hetauda, Makawanpur (Sahay et al., 1992); China 
(Hu and Wei, 2006), India (Arulmurugan et al., 2010).

7. Pediastrum tetras (Ehrenberg) Ralfs [Current accepted name Stauridium tetras (Ehrenberg) E. Hegewald] (Fig. 2)

Tiffany, L.H. and M.E. Britton 1952, P. 110, Pl. 30, Fig. 293; Philipose, M.T. 1967, P. 128, Figs. 45a-c; Komarek, J. 1983, P. 83, Pl. 4, Fig. 11; Prasad, B.N. and P.K. Misra 1992, P. 11, Pl. 1, Fig. 9.

Colonies rectangular, oval or circular, of 48-16 celled, without intercellular spaces; marginal cells divided into two lobes by a deep linear to cuneate incision on the outer side reaching to the middle of the cell; each lobe truncate, slightly emarginated or further divided into two lobes; inner cells 46 sided with a single linear incision; colonies $12-16 \mu \mathrm{m}$ in diameter; cells $5-15$ $\mu \mathrm{m}$ in diameter.

L : Planktonic in the small puddle at the bank of Leguwa river near Arun Khola, 475 m, Dhankuta.

CN : SK 112, DC : 18-08-2011.

D : Nepal - A pond at Ankhu Khola, 640 m, and Luitel Bhanjyang, $770 \mathrm{~m}$, Gorkha (Hirano, 1955; Nakanishi, 1986); Stream at Khumbu, 2000 m (Kusel-Fetzmann, 1969) and Sanegang, $2500 \mathrm{~m}$ (Hirano, 1983), Solukhumbu; Small pond south of Rara lake, $3030 \mathrm{~m}$, Mugu (Watanabe, 1995); China (Hu and Wei, 2006), India (Mahendraperumal and Anand, 2008; Arulmurugan et al., 2010), Iran (Afsharzadeh et al., 2003), Taiwan (Anon., 2012 ), Turkey (Soylu and Gönülol, 2006).
8. Pediastrum tetras var. apiculatum Playfair (Fig. 3)

Fritsch, F.E. and Stephens 1921, P. 10, Figs. 2 A-D; Prescott, G.W. 1951, P. 227, Pl. 50, Fig. 7 (as P. tetras var. tetraodon); Philipose, M.T. 1967, P. 130, Fig. 45h.

It has similar characters with $P$. tetras except its processes with apical nodular thickening; Colonies $25 \mu \mathrm{m}$ in diameter; cells $14.5 \mu \mathrm{m}$ long, $17.5 \mu \mathrm{m}$ broad.

L : Epiphytic on the root of Eichhornia crassipes (Mart.) Solms at Raja Rani lake, $700 \mathrm{~m}$, Bhogateni, Morang.

CN : SK 50, DC : 17-06-1011.

D: Nepal - Fish pond, Hetauda, Makawanpur (Sahay et al., 1992); India (Philipose, 1967).

9. Pediastrum tetras var. excisum (Rabenh.) Hansg. [Current accepted name $P$. tetras (Ehr.) Ralfs] (Fig. 1)

Philipose, M.T., 1967, P. 129, Fig. 45f; Prasad, B.N. and P.K. Misra 1992, P. 12, Pl. 1, Fig. 12.

Marginal cells with more or less deeply concave lobes, rest are similar as in $P$. tetras; colonies $18.5 \mu \mathrm{m}$ in diameter; cells $10.5 \mu \mathrm{m}$ long, $12 \mu \mathrm{m}$ broad.

$\mathrm{L}$ : Benthic on the pebbles at Triyuga river, $152 \mathrm{~m}$, Gaighat, Udayapur.

CN : SK 61, DC : 26-06-2011.

D : Nepal - Bakeya river (Sahay et al., 1992); India (Arulmurugan et al., 2010). 
S.K. Rai and P.K. Misra / Our Nature (2012) 10: 167-175

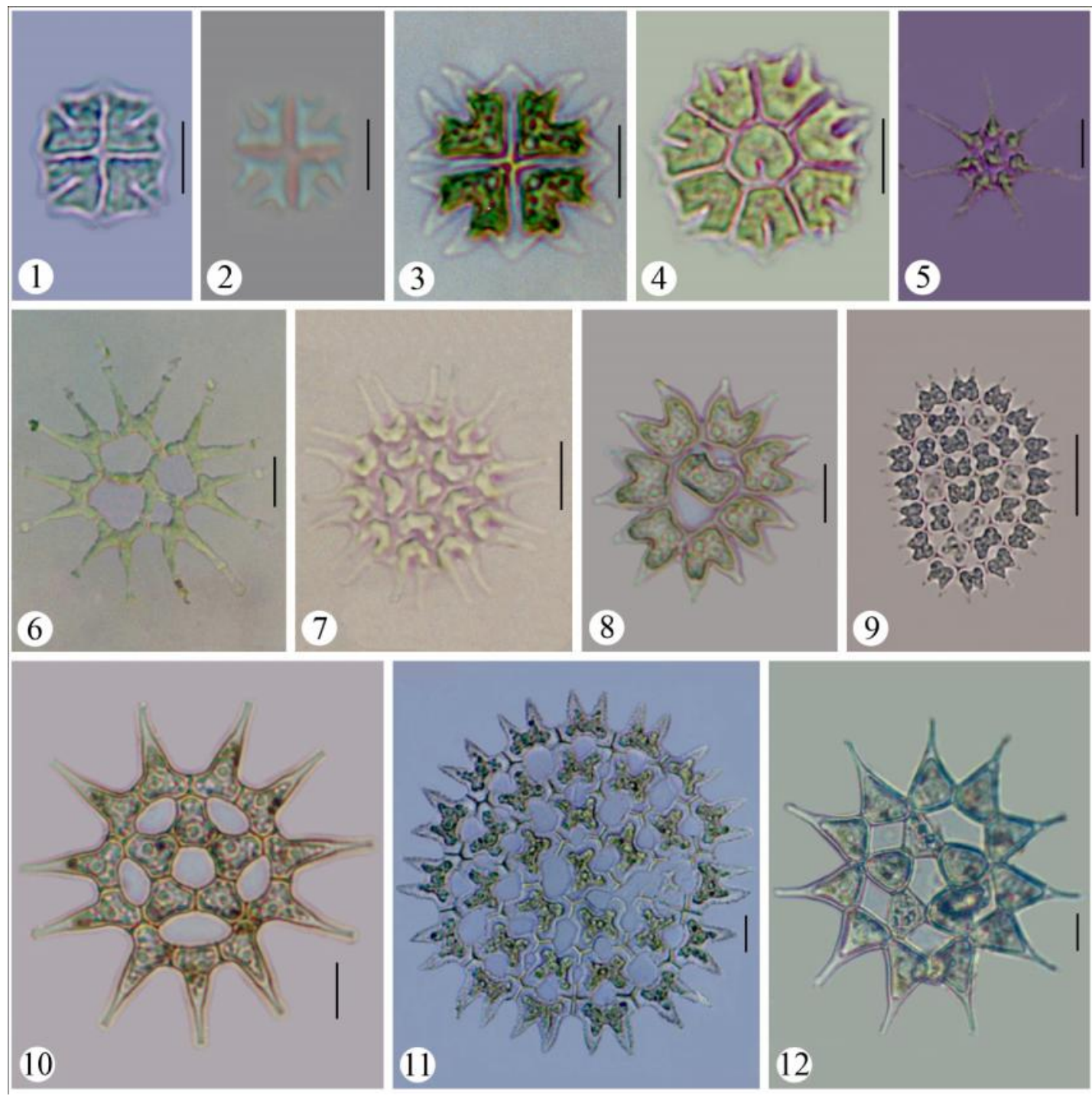

Figures: 1. Pediastrum tetras var. excisum, 2. P. tetras, 3. P. tetras var. apiculatum, 4. P. tetras var. tetraodon, 5. P. simplex, 6. P. duplex var. gracillium, 7. P. boryanum var longicorne, 8-9. P. duplex, 10. P. simplex var. duodenarium, 11. P. duplex var. subgranulatumi, 12. P. simplex. (Scale bars measure $10 \mu \mathrm{m}$ )

10. Pediastrum tetras var. tetraodon Colonies 4-8-16 celled; incision of cells (Corda) Hansgirg (Fig. 4) deep with the lobes adjacent to the incision of the marginal cell; colonies $30 \mu \mathrm{m}$ in

Tiffany, L.H. and M.E. Britton 1952, P. diameter; marginal cells $10 \mu \mathrm{m}$ long, 9-10 112, Pl. 30, Fig. 294; Philipose, M.T. 1967, $\mu \mathrm{m}$ broad; inner cells $8.5 \mu \mathrm{m}$ long, $9.5 \mu \mathrm{m}$ P. 129, Fig. 45g; Prasad, B.N. and P.K. broad. Misra 1992, P. 12, Pl. 1, Figs. 7, 10. 
L : Epiphytic on the root of Pistia stratiotes L. at Sarouchia pond, $72 \mathrm{~m}$, Biratnagar, Morang.

CN : SK 46, DC : 13-06-2011.

D : Nepal - A pond at Ankhu Khola, 640 m, Gorkha (Hirano, 1955); Small pond at Gadda Chauki, Mahendranagar, Kanchanpur (Chaturvedi and Habib, 1996); China (Hu and Wei, 2006), India (Arulmurugan et al., 2010), Iran (Ramazannejad Ghadi, 2008).

The study revealed that the genus Pediastrum is not restricted at the centre and west but also distributed towards the eastern part of Nepal mainly at the hot and humid Terai plain where lentic habitats are common. A total 20 taxa of Pediastrum belonging to its 9 species are recorded from Nepal including the present 10 taxa (Tab. $1)$.

\section{Acknowledgements}

Authors are thankful to the Head, Department of Botany, University of Lucknow, India for laboratory and photomicrography facilities. Thanks are also due to Prof. Dr. S. Jha, Head, Department of Botany, P.G. Campus, T.U., Biratnagar for library facility. The first author acknowledges the University Grants Commission, Nepal for research grant.

\section{References}

Afsharzadeh, S., T. Nejadsatari, M.R. Rahiminejad and M. Ebrahimnejad 2003. Study of algal flora in Zayanderood river. Iranian Journal of Biology 14: 32-45.

Anonymous 2012. Biota Taiwanica. Algae of Taiwan. Checklist. Retrieved from http://algae.biota.biodiv.tw/ catalog; searched on 13 September, 2012.

Arulmurugan, P., S. Nagaraj and N. Anand 2010.
Biodiversity of fresh water algae from temple tanks of Kerala. Recent Research in Science and Technology 2(6): 58-71.

Baral, S.R. 1999. Algae of Nepal. In Nepal Nature's Paradise (Eds. T.C. Majupuria and R. Kumar), Gwalior, India. pp. 655-681.

Biswas, K. 1949. Common fresh and brackish water algal flora of India and Burma. Records bot. Surv. India 15(1): 1-105.

Bruehl, P. and K. Biswas 1926. Algae of Loktak lake. Mem. Asiatic. Soc. Bengal. 8(3): 257-315.

Cao, X., A. Strojsová, P. Znachor and E. Zapomelová 2005. Detection of extracellular phosphatases in natural spring phytoplankton of a shallow eutrophic lake (Donghu, China). European Journal of Phycology 40: 251-258.

Chaturvedi, U.K. and I. Habib 1996. A systematic account of Chlorococcales from Nepal, Phykos 35(1-2): 129-137.

Das, S.N. and B.N. Verma 1996. Algal flroa of Chitwan and Nawalparasi districts of Nepal. Phykos 35(1-2): 119-127.

Fritsch, F.E. and Stephens 1921. Contribution to our knowledge of the freshwater algae of Africa-III. Freshwater algae (exclusive of diatoms) mainly from the Transkei Territories. Trans. roy. Soc. S. Afr. 9(1): 1-72.

Hickel, B. 1973. Limnological investigations in lakes of Pokhara valley, Nepal. Int. Rev. ges Hydrobiol. 58(5): 659-672.

Hirano, M. 1955. Fresh water algae. In Fauna and flora of Nepal Himalaya (Ed. H. Kihara), Fauna and Flora Research Society, Kyoto University, Kyoto, Japan. pp. 5-42.

Hirano, M. 1963. Fresh water algae from the Nepal Himalaya, collected by a member of the Japanese Climbing Expedition. Contr. Biol. Lab., Kyoto Univ., Japan. 16: 1-23.

Hirano, M. 1983. Fresh water algae from Bhutan. Stud. Rep. Baika Junior Coll. 31: 171-183.

$\mathrm{Hu}, \mathrm{H}$. and Y. Wei 2006. The freshwater algae of China. Systematics, taxonomy and ecology, China. pp. 1-1023. Retrieved from http://www.sciencep.com

Komárek, J. 1983. Contribution to the Chlorococcal algae of Cuba. Nova Hedwigia 37(1): 65-180.

Komárek, J. and V. Jankovská 2001. Review of the green algae genus Pediastrum; Implication for pollen-analytical research. Bibl. Phycol., Cramer J. Berlin-Stuttgart. 108p.

Kowalska, J. and K. Wolowski 2010. Rare Pediastrum species (Chlorophyceae) from Polish 
S.K. Rai and P.K. Misra / Our Nature (2012) 10: 167-175

coastal lakes. Acta Societatis Botanicorum Poloniae 79(3): 225-233.

Kusel-fetzmann, E. 1969. Einige Algen aus Nepal. Khumbu Himal (Berlin) 1(6): 37-56.

Mahendraperumal, G. and N. Anand 2008. Manual of fresh water algae of Tamilnadu. Bisen Singh and Mahendrapal Singh Publ, Dehra Dun, India. 124p.

Mehwish, H. and R. Aliya 2005. Occurrence of freshwater algae at different localities of Karachi University. Int. J. Phycol. Phycochem. 1(2): 117124.

Nakanishi, M. 1986. Limnological study in Phewa, Begnas and Rupa lakes. In Studies on distribution, adaptation and evolution of microorganisms in Nepal Himalayas (Second report) (Ed. Y. Ishida), Ministry of Education, Science and Culture, Kyoto, Japan. pp. 3-13.

Parra, O.O. 1979. Revision der gattung Pediastrum Meyen (Chlorophyta). Bibl. Phycol. 48: 1-186.

Pasztaleniec, A. and M. Poniewozik 2004. Pediastrum species (Hydrodictyaceae, Sphaeropleales) in phytoplankton of Sumin lake (Leczna-Wludawa Lakeland). Acta Societatis Botanicorum Poloniae 3(1): 39-46.

Pham, M.N., H.T.W. Tan, S. Mitrovic and H.H.T. Yeo 2011. A checklist of the algae of Singapore. Singpore: Raffles Museum of Biodiversity Research, National University of Singapore. 100p.

Philipose, M.T. 1967. Chlorococcales, I.C.A.R. monograph on algae, New Delhi. 365p.

Prasad, B.N. and P.K. Misra 1992. Fresh water algal flora of Andaman and Nicobar islands. Vol. 2. Bishen singh and Mahendrapal Singh Publ, Dehradun, India. 284p.

Prasad, V. 2011. Modern check-list of algae of Nepal.
Heritage Publishers and Distributors Pv. Ltd., Kathmandu, Nepal. 85p.

Prescott, G.W. 1951. Algae of the western great lakes area. WM.C. Brown Publishers, Dubuque, Iowa. 977p.

Ramazannejad Ghadi, R. 2008. Epipelic algae of Miankaleh International Wetland (North of Iran). In Proceeding (Full paper) in the 1st National Congress on Fishery Resources of Caspian Sea. Gorgan University of Agricultural Sciences and Natural Resources. 18-19 Nov.

Sahay, A.P., P.K. Das and B.N. Verma 1992. Studies on the algal flora of Nepal-I: Chloro-phyceae. Geophytology 20(2): 155-158.

Soylu, E.N. and A. Gönülol 2006. Seasonal variation in the diversity, species richness and composition of the phytoplankton assemblages in a shallow lake. Cryptogamie Algologie 27: 85-101.

Tiffany, L.H. and M.E. Britton 1952. The algae of Illinois. Hafner publishing Co., New York. 407p.

Watanabe, M. 1995. Algae from lake Rara and its vicinities, Nepal Himalayas. In Cryptogams of the Himalayas (Eds. M. Watanabe and H. Hagiwara), Vol. 3, Nepal and Pakistan, National Science Museum, Tsukuba, Japan. pp. 1-17.

Wendy Guiry in Guiry, M.D. and G.M. Guiry 2012. AlgaeBase. World-wide electronic publication, National University of Ireland, Galway. Retrieved from http://www.algaebase.org; searched on 15 October, 2012.

Yamamoto, Y. and F.-K. Shiah 2012. Factors relating to the dominance of Cylindrospermopsis raciborskii (Cyanobacteria) in a shallow pond in northern Taiwan. Journal of Phycology 48(4): 984-991. 